\title{
Mobile instant messaging: a bonanza for interlanguage pragmatics
}

\author{
Mensajes móviles instantáneos: una bonanza para la pragmática de interlengua
} \\ Universidad de Sevilla, Filología Inglesa, Sevilla, Spain
}

\section{ABSTRACT}

While mobile communication technologies have been exploited for instructional second and foreign language (L2) research, authentic mobile instant messaging (MIM) interactions remain virtually unexamined. As a result, decidedly little is known about L2 users' interlinguistic behavior in genuine MIM conversation. This type of communication may nevertheless be of interest to interlanguage pragmatics (ILP) research, particularly for what it may reveal about the intersection of cultures and electronically-mediated communities. This article traces the current state of related research and contemplates some preliminary conceptual and methodological considerations for future inquiries. It first reviews previous L1 and L2 studies involving mobile and instant messaging mediums. From among these, it notes two underexplored concepts which are relevant to ILP: namely, interculture and cultures-of-use. Respectively related to co-constructed culture and communities of practice, these aspects may shed light on and be illuminated by interlinguistic MIM interaction. Finally, the article looks to future investigations and, while not specifying analytical procedures, it recommends emic methods such as conversation analysis for examining these phenomena.

Keywords: Conversation analysis; Cultures-of-use; Intercultural communication; Interlanguage pragmatics; Mobile instant messaging.

\section{RESUMEN}

Aunque las tecnologías de la comunicación móvil se han empleado para investigar la enseñanza de segundas lenguas y lenguas extranjeras (L2), no se ha estudiado tanto la interacción natural entre hablantes no-nativos mediante mensajes móviles instantáneos (MIM). Por tanto, se dispone de escasa información sobre el comportamiento interlingüístico en conversaciones reales de MIM. Este tipo de comunicación, sin embargo, puede ser de gran interés para estudiar la pragmática de interlengua (ILP), particularmente por lo que puede revelar sobre la intersección de culturas y comunidades mediatizadas por las nuevas tecnologías. Este artículo contempla el estado actual de estas cuestiones y hace algunas consideraciones conceptuales y metodológicas para futuras investigaciones. En primer lugar, repasa algunos estudios sobre la comunicación en una L1 y L2 a través de dispositivos móviles y mensajes instantáneos. De éstos, destaca dos conceptos poco explorados, pero muy relevantes para la ILP: concretamente, la intercultura y las culturas de uso. Dada su relación con las culturas co-construidas y las comunidades de práctica respectivamente, ambos conceptos pueden ayudar a comprender la interacción interlingüística MIM, a la vez que se pueden analizar en la misma. Finalmente, el artículo señala posibles futuras investigaciones y, aunque no pormenoriza procedimientos analíticos concretos para estudiar la interacción interlingüística MIM, recomienda el uso de métodos émicos, tales como el análisis de conversación.

PALABRAS CLAVE: Análisis de conversación; Culturas-de-uso; Comunicación intercultural; Pragmática de interlengua; Mensajes móviles instantáneos. 


\section{Introduction}

lobalization has eventuated parallel flourishing in two fields of linguistic Ustur tudy: intercultural communication and electronically-mediated communication (EMC). The first evolves from sociocultural disciplines: it considers interaction between people across social and languacultural distinctions. As such, it generally subsumes interlanguage and L2 use, at least in communication between interactants of two different L1s using a common L2 (as in lingua franca studies), or between native and non-native speakers of the language of transmission. As intercultural communication may not always involve non-native speakers (such as in inter-dialectal exchanges), intercultural communications involving at least one L2 user are referred to here as interlinguistic intercultural communication.

The second field, EMC, also covers a range of oral and written communication types, but gives attention to their mediation through technological platforms. This area of inquiry includes its better-known precursor, computer-mediated communication (typically PC-to-PC interaction through web-based chat, e-mail, etc.), but extends to portable devices and mobile phones (e.g., SMS messaging and mobile apps). Because electronic mediums facilitate communication across languages and cultures, intercultural communication and EMC research often addresses overlapping issues, and such inquiries are of direct interest to interlanguage pragmatics. However they are only beginning to be tackled concomitantly, as pioneered by Shuter's (2012) Intercultural New Media Studies. A conspicuous deficit in empirical data nevertheless persists.

To consider the intersection of these areas of inquiry, the current article focuses on interlinguistic intercultural communication through one of the most prominent electronic mediums: mobile instant messaging. Mobile instant messaging, or MIM, lays claim to a significant portion of private communications in general: $65 \%$ of people worldwide use SMS/text messaging alone, not including third-party messaging applications (SLICKTEXT). The most popular external MIM application, WhatsApp, had 1.5 billion users as of 2017 (approximately $20 \%$ of the population), one billion of whom ( $13 \%$ of the population) used the app daily (CONSTINE, 2018). While many MIM texters also use SMS and phone calls, reports show that $33 \%$ of mobile phone users prefer written messages to phone calls (WISE, 2018). Averages also indicate that communication via text messaging is ten times faster than through phone calls, and Americans text twice as often as they call (RUFFERTY, 2017). Mobile messaging's extended use renders all the more surprising the paucity of investigation into its role in intercultural communication, and interlanguage use therein.

This article takes a first step towards filling this lacuna by compiling previous findings and addressing some considerations for future investigation. The following section reviews relevant research on mobile-mediated interlanguage use, highlighting thereafter the pressing need for non-instructional investigation. However, this much needed research implicates dynamic intercultural and multimodal aspects, as discussed in the third and fourth sections. The third section looks briefly at the concept of interactionally-constructed interculture in interlinguistic intercultural communication. The fourth considers the underexplored notion of cultures-of-use (similar to communities of practice) and their negotiation through multimodal EMC resources. As suggested here, interculture and cultures-of-use are integral to MIM interactions involving L2 users. As such, the fifth section calls for modernized analytical methods which give ample attention to these aspects. While the article does not spell out specific steps for analysis, it suggests that future researchers pursue conversation analysis or other data-driven methods to account for interlinguistic, intercultural, and multimodal EMC phenomena. The closing section consolidates these views and calls for further investigation.

\section{Literature review}

MIM is used here to refer to personal-messaging communication managed from tactile, internet-capable portable devices, typically smartphones. These platforms may include transmission of text, images, icons like emojis and stickers, audio and video recordings, and other multimedia like GIFs. Thus MIM mediums are taken here to include internal applications (a mobile device's preinstalled messaging services, e.g., SMS or iMessage) and external ones (thirdparty or internet-downloaded services, e.g., WhatsApp or Telegram) used to communicate with personal contacts. As messages are sent instantly, and will 
arrive at their destination as soon as it is available, these applications permit both synchronous and asynchronous communication. MIM differs from audio phone or video conferencing (e.g., FaceTime) mediums not only because it is text-based, but because interaction is possible both in (quasi) real-time when both or all interactants are available and active, or when only one user participates at a time.

Before smartphones, perhaps the most similar mediums were SMS or textmessaging (because they took place on mobile devices) and instant messaging (because these web-based chats offered fewer/no message-length or cost restrictions, and because they could be composed on an expanded keyboard nearly as rapidly as face-to-face conversations). These parallel MIM precursors share some basic characteristics with each other and with MIM, such as optionality of greetings and closings, persistent connectivity, reciprocal turns, and informal talk (SPAGNOLLI; GAMBERINI, 2006). Computer-mediated instant messaging, for its part, has been classified as an original and hybrid form of written computer-mediated discourse and oral conversation (CRYSTAL, 2006; YUS, 2011), but it lacks the mobile connectivity afforded by text messaging. As a result, users have been observed to make somewhat differential use of each, leading to widespread discussion of medium effects (HERRING, 2001, p. 614). For instance, Baron (2008) reported a quantitative comparison of instant messaging and SMS messaging, yielding the following findings:

(1) Overall similarities in use

a) Emoticons and acronyms - infrequent in both, with a few more emoticons in instant messaging

b) Punctuation - both favored punctuation in message-internal sentences, while most messages omitted transmission-final punctuation, but maintained question marks regardless

(2) Overall differences in use

a) Message length - slightly less lexical variety, more words and characters used in text messages (presumably because of character limitations and message costs in SMS, as well as increased effort needed for keystrokes)

b) Contractions with apostrophes - more contractions in text messages and with considerably fewer apostrophes.
In electronically-mediated messaging then and now, technological constraints and capabilities leave their mark, as seen above. McSweeney claims in stark terms that "any language that is mediated through a mechanical or computational technology will necessarily homogenize users' language practices" (2018, p. 2). As an illustration of this homogenization, she mentions automatic correction's hampering of codeswitching in texting.

Medium effects are nonetheless limited - even when focusing on mobile channels with similar properties, communication therein is "often highly unpredictable from an 'affordance' perspective because technological (and multimodal) forms and social practices are co-constituted" (LEANDER; VASUDEVAN, 2009, p. 129). Thus mobile interaction is "not univocal, but subject to cultural preferences and habits" (SPAGNOLLI; GAMBERINI, 2006). A number of factors influence use, from external contexts (including culture) and participant characteristics to interface-related aspects (the communications' infrastructure) and functional goals (BAYM, 1995). Essentially, there is no uniform "language of texting" because mobile messaging constitutes "communicative events (i.e., genres)", a function rather than a form of writing (THURLOW; POFF, 2013, p. 178). Idiosyncrasies, cultural norms, and communities of practice (WENGER, 1998) all play into how users view and employ these functions.

Instant messaging, or internet chat written through a computer, is not new to ILP thanks to its renown in instructional pragmatics. Several studies have remarked on this medium's capacity for developing intercultural communication (CHUN, 2011), vocabulary learning (BLAKE, 2000), interpersonal relations (VANDERGRIFF, 2013), pragmatic competence (GONZÁLEZ-LLORET, 2008; SYKES, 2005), and overall language learning (ZENG; TAKATSUKA, 2009). Realized in classroom settings, most of the studies mentioned have involved L2 students interacting with their non-native peers, with the exception of Chun's (2011) exchange between learners of two different target languages (German and English).

Instant messaging is perhaps the most widely-reported computer-mediated tool for language learning and telecollaboration. This is not without cause: written synchronous chat shows advantages over face-to-face conversation (SYKES, 2005; WARSCHAUER, 1996), oral chat (SYKES, 2005), and forum posts (CHUN, 2011) in terms of learners' language production, communicative success, motivation, and extent and distribution of participation. Unsurprisingly, instant messaging often allows for more lexical and syntactic complexity than face-to-face conversation 
due, in part, to the extra processing time (WARSCHAUER, 1996). In turn, instant messaging often engenders less syntactic complexity than asynchronous chat (e.g., discussion threads), related to the former's encouragement of multiple short turns versus the latter's more monological tendencies (SOTILLO, 2000). On the other hand, interpersonal work proliferates in synchronous chat (CHUN, 2011).

More recently, L2 learning via mobile devices (under the monikers of mobile learning, m-learning, and Mobile-Assisted Language Learning or MALL) has expanded to include a number of application types on various portable devices (e.g., DUCATE; LOMICKA, 2013; SONG; FOX, 2008). Some of this attention has been dedicated to MIM, and in particular to the application WhatsApp (MORATÓ-PAYÁ, 2014). Ostensibly, WhatsApp can serve as a logistical classroom tool, e.g., for teacher-student contact (BOUHNIK; DESHEN, 2014) and out-of-class group work (AVCI; ADIGUZEL, 2017). Even in functional capacity, it may foster interpersonal relations which enhance the learning environment (AVCI; ADIGUZEL, 2017; BARHOUMI, 2015). Moreover, as seen with pre-smartphone text messaging, vocabulary learning may also be directly targeted through mobile messages (LEVY; KENNEDY, 2005) - but also, student interaction via WhatsApp can lead to untargeted and incidental development in writing (ANDÚJAR, 2016) and reading skill (GUTIÉRREZ-COLÓN; GALLARDO-TORRANO; GROVA, 2013). Even so, Burston (2014) considers that MALL is "still on the fringes" of L2 teaching practice.

Mobile devices can potentiate learning precisely because they are primarily communicative rather than educational to most users, and so they can encourage L2 learning autonomy (GONZÁLEZ-LLORET, 2010). Students with mobile devices have been reported to use them for informal L2 use and learning as much, if not more, than for class-related or assigned activities (CLOUGH et al., 2009; DASHTESTANI, 2016; DUCATE; LOMICKA, 2013). As Thorne points out, networked technologies facilitate access to

intercultural communication in the wild - situated in arenas of social activity that are less controllable than classroom or organized online intercultural exchanges might be, but which present interesting, and perhaps even compelling, opportunities for intercultural exchange, agentive action and meaning making. (2010, p. 144, original emphasis)
In fact, proponents of multiliteracy (see COPE; KALANTZIS, 2015) advocate the inclusion of multimodal internet and mobile genres as an object in foreign language teaching (THORNE; REINHARDT, 2008). What remains in the dark is research analyzing the product of this informal use, especially in terms of L2 MIM communication.

This review reflects that mobile communication does indeed appear in interlanguage literature, but pedagogical accounts make up nearly the whole of it. As a result, little to no research covers genuine MIM data by L2 users (SHUTER, 2012). A partial exception appears in Haggan (2010), which investigates how well native raters could predict whether natural text messages were produced by native or non-native English speakers. While Haggan explicitly states pedagogical aims and implications, the rating component of her study was not instructional and instead utilized authentic, one-line messages. Her findings indicate that overall, raters were unable to distinguish native and non-native messagers. She concludes that these users' native-like achievement is "unusual and valuable" from a pedagogical perspective (HAGGAN, 2010, p. 156). The zoomed-in focus facilitated and controlled this study - participants were able to provide ratings with ease thanks to the limited selection of brief messages. But trimming the data for this purpose actually required the elimination of pertinent intercultural aspects, such as codeswitching (messages with switches were excluded), interlocutor identity, conversational context and situation. While understandably challenging for data collection and analysis, the unabridged and contextualized interactions of these interlanguage users would nevertheless have been of exceptional value to ILP.

Aside from this study, minimal research has taken a cross-cultural approach, for instance contrasting texting practices between users in India and the U.S. (SHUTER; CHATTOPADHYAY, 2010) and Swiss native speakers of five respective languages (UEBERWASSER; STARK, 2017). The findings have suggested that some aspects of mobile communication may be culturally-correlated, while others reflect more globalized practices. However, ILP research has yet to delve into interlinguistic intercultural phenomena or the interplay of medium-adapted cues. 


\section{Interculture}

Traditionally, ILP studies have examined the behavior and development of interlanguage speakers in elicited or informal settings. To do so, they have typically focused on interlanguage phenomena in isolation, contrasting individuals' interlanguage use to their L1 behavior or to the L1 behavior of native speakers of the target language. When viewed in intercultural interaction, however, L2 use manifests "both an a priori side and an emergent side that occur and act simultaneously in the communicative process" (KECSKÉS, 2012, p. 69). Authentic interlinguistic intercultural communication can reflect, therefore, how L2 users employ not only prior knowledge, but knowledge co-created in situ.

On the one hand, L2 users in natural intercultural communication may suspend learning-related, form-focused concerns in favor of modified conversational principles (KASPER, 1988, p. 137). Particularly in exchanges with other non-native speakers, L2 users behaving cooperatively may prioritize semantically unambiguous language (e.g., direct forms) and avoid language they cannot guarantee their interlocutor will understand (e.g., figurative forms of language and culture-specific sociopragmatic norms) (HOUSE, 2003; KECSKÉS, 2008). This not only facilitates communication, but conveys solidarity and benevolence (MEIERKORD, 2000).

In addition to this conscientious use of (supposed) shared linguistic knowledge, interactants negotiate meanings in the two-way development of an "intercultural discourse" as well as a "discursive interculture" (KOOLE; TEN THIJE, 2001, p. 572). In other words, the interactants' cultural strains blend in the discourse between them and this, in turn, weaves a dynamic, private culture therein. This plays out in conversational meaning transmission, as well - " $[t]$ here is more reliance on language created ad hoc by individuals in the course of interaction than on prefabricated language and pre-existing frames" (KECSKÉS, 2014, p. 2). That is, where interactants assume more limited mutuality, they make extra use of the common ground evidenced or established in the course of their relationship/interaction.

Lingua franca studies, which focus on L2-L2 communication between speakers of dissimilar mother tongues, have given particular attention to this dynamic aspect of interculturality. They reveal that lingua franca users not only negotiate meanings of terms and topics, but also conversational conventions such as admittance of overlap and interruption (MEIERKORD, 2000). Through such negotiation, lingua franca and other intercultural interactions are creative and overwhelmingly successful - particularly when viewed from a discourse standpoint. Despite ILP's traditional focus on negative pragmatic transfer and pragmatic failure, misunderstandings are infrequent in intercultural data (HOUSE, 2003; KECSKÉS, 2008). Viewed across multiple turns at talk, misunderstandings even more rarely hamper communication (FIRTH, 1996; MAURANEN, 2006). Thus intercultural communication research offers the reminder that interlanguage users may in fact make considerably more appropriate contributions than not, and they moreover employ strategies to achieve understanding in spite of possible glitches. How this is achieved is of interest to ILP, but must be viewed across turns. As a dialogic medium, MIM provides an interesting environment for viewing interlinguistic intercultural exchanges held therein. At the same time, the writing-based electronic medium plays a part.

\section{Cultures-of-use}

Interculture takes on a singular gleam when mediated through written electronic platforms. In MIM, as in intercultural communication, "certain minimum alignments of cultures-of-use are a necessary condition" (THORNE, 2003, p. 57). Intercultures intersect with communities of practice in this environment, because "the cultures-of-use of a communicative medium - its perceived existence and construction as a cultural tool - may differ interculturally just as communicative genres and personal style may differ interculturally" (THORNE, 2003, p. 57). In other words, individuals and groups may hold diverging expectations related to mediated-interaction pragmatics. However cultures-of-use are also constructed in conversation as interactants optimize communication and foster ties therein. Users' own continued practices create perceived marked and unmarked options by which selection is meaningful and socially relevant (MYERS-SCOTTON, 1998). Establishing contact via MIM as opposed to e-mail, for instance, factors into culture-of-use practices because the mediums themselves are not neutral: "individual and collective experience" lend them social significance as "distinctive cultural artifacts" (THORNE, 2003, p. 38). 
Inevitably, interactants' experiences in MIM cultures-of-use involve multimodal resources. The verbal and nonverbal cues adopted and adapted to enhance communication are varied and robust in their effects. For instance, Walther, Loh, and Granka (2005) reported that in written instant messaging, users achieved uncompromised interpersonal affiliation by replacing faceto-face nonverbal means with verbal cues. This finding supports prior claims that electronic mediums furnish users with a hyperpersonal channel, equal or superior in emotive expression as compared to face-to-face conversation (WALTHER, 1996). But nonverbal signals nonetheless thrive in written mediums: punctuation and symbols, paralinguistic renderings, and other typographical modifications are just some ways users create "mediated gestures" (SCHANDORF, 2012). Their effects are even more extensive: just emojis and emoticons go far beyond the typically-ascribed function of emotional display to perform an array of pragmatic functions (DRESNER; HERRING, 2010; YUS, 2014).

Hyperpersonality may be all the more evident in current MIM technologies where a plethora of tools permit varied modes of expression. Users' personal, and often informal, connections may be better realized through visuallyremoved communication (that is, EMC like MIM not including video conferencing features), in part because it permits enhanced self-presentation and otherperception - commodities all the more important in a "phatic culture" (MILLER, 2008). Walther's (1992) Social Information Processing theory contends that users will make up for audio-visual restrictions through primarily linguistic means. At the same time, he supposes that "[b]ecause verbal communication with no nonverbal cues conveys a fraction of the information of multimodal communication, communication functions should require a longer time to take place" (WALTHER, 2011, p. 458). However modern technologies offer vastly wider and more socially-expanded tools than did the sideways-smiley emoticons available at the theory's conception. In addition to increased cue options, mobile interaction may be more frequent than face-to-face contact: touch-screen devices permit relatively rapid message-composition and message receivers are more likely to be connected. As such, de facto modern MIM use may considerably diminish this lag, if not overcome it.

In brief, users make MIM communicatively and relationally effective by exploiting a range of its tools, and this evidence suggests that both medium and mode combine to facilitate and enhance users' transactions and relationships.
Moreover, as a social practice, these mediums and their modal resources evolve into cultures-of-use among communities and between individual users. These interactions would be expected, like intercultural communication, to entail a priori and emergent characteristics, norms and negotiated styles. Compounded with interlinguistic aspects, MIM communication cannot be extrapolated from elicited classroom data; rather, it merits focused attention in its natural environment. Future research would do well to consider this juncture in authentic L2 use in MIM communication, but it should be informed by and alert to intercultural and multimodal culture-of-use phenomena.

\section{Future analysis}

As purported in the literature review, there is an unaccountable discrepancy between elicitation-based ILP studies and research which analyzes genuine data in interlinguistic intercultural EMC, and yet the latter is essential to understanding interlanguage in interaction. Bardovi-Harlig (2010, p. 242) has cited EMC's interest to ILP for analyzing written genres, but she cautions that authentic interaction must be the basis. Natural conversation through MIM presents its own methodological challenges, nonetheless. For example, units of analysis are blurry in MIM communication. "Conversation" often appears immeasurable (ALCÁNTARA-PLÁ, 2014) - omission of greetings and closings, intercalated topics, implicit cohesion and retractable coherence give the impression of constant ongoing-ness. These features are moreover unrepresented in other oral and written forms - "perpetual contact" is a unique and defining element of mobile communication (KATZ; AAKHUS, 2002). This inhibits certain traditional approaches, such as the analysis of adjacency sequences, conversational phases, and some amount of turn-taking (SACKS; SCHEGLOFF; JEFFERSON, 1974).

Of course, a methodology for analyzing electronic communication need not come from scratch. With a view to accommodating ethnomethodology to instant messaging analysis, Herring (2007) has recommended that research in EMC more consistently define medium-related aspects and their interplay with social factors. To do so, she elaborated a faceted classification scheme for pragmatic analysis. This scheme offered several categories relating to a medium's temporal 
and spatial capacity, the tools offered, and how it connected users. Social factors, on the other hand, included participant characteristics, conversational activity and aims, modes of expression, and norms of participation. Herring's scheme draws attention to aspects which may differ between across mediums and situations. However a certain amount of emic, or data-driven, scrutiny may be required to account for some of these features.

Conversation analysis, in particular, may offer promising groundwork for such an approach: its bottom-up procedure leaves wide contours for analyzing multimodal complexities in digital discourse (e.g., CONNOLLY; PHILLIPS, 2005; GONZÁLEZ-LLORET, 2010). It may also allow for simultaneous micro and macro visions of intercultural and interlinguistic behavior (FIRTH, 1996; GIBSON, 2009). For instance, conversation analysis can view interactional behavior up close from (1) reception/responses which may reflect interpretation of acts and of im/polite behavior and (2) reciprocal moves which may indicate consensus of behavior. As such, it lends itself to meaning reconstruction (KOOLE; TEN THIJE, 2001), or a reconstrual of meaning according to conversational evidence of interlocutors' interpretations. These methods can also illuminate nonverbally-expressed intentions in EMC, such as non-emotional emoticons for which a "nonconventional, explanatory framework is required" (DRESNER; HERRING, 2010, p. 262).

At the same time, conversation analysis can consider norms and meaning negotiated discursively and diachronically beyond initiation-response sequences. This is important in interlinguistic intercultural communication because interactants obtain perlocutionary effects through collaborative, multi-turned efforts. That is, even more so than native speakers, L2 interactants achieve understanding on a discourse level rather than an utterance level (KESCKÉS, 2014). Consequently, interlanguage conversation analysis requires a view to complex actional unfolding. This complexity increases in synchronous MIM, where users themselves tacitly adapt to a "loosened relevance" in the face of spontaneous disadjacencies and other ambiguities (HERRING, 2013). Even more confounding is the multi-dimensionality of user networking - contact may be dispersed between social media and face-to-face exchanges, leaving or removing its traces from MIM interaction. But precisely this polyvalence may contribute to these mediums' social capital and their conduciveness to enhanced interpersonal relations (MILLER, 2008; SHUTER, 2012).
In a sense, EMC, like all communication, "is to some degree intercultural" - people use it to engage between and within groups through multiple discourse systems, creating what might be better described as interdiscourse communication (SCOLLON; SCOLLON; JONES, 2012, p. 2). In many aspects, geopolitical definitions of culture may also be eclipsed by user-constructed virtual or glocal domains (LEANDER; VASUDEVAN, 2009). The responsibility, and the risk, of navigating these dimensions and identifying ad hoc interactional phenomena falls in the hands of the analyst, who may be tempted to erroneously interpret correlations between participant behavior and medium or culture. Thus MIM conversations involving L2 speakers should first and foremost be "regarded and analyzed as ordinary communication" (KOOLE; TEN THIJE, 2001, p. 571). Defining "ordinary" exceeds the scope of this article - but conceptualizing it may yet be informed and expanded by intercultural and EMC considerations.

\section{Closing remarks}

It should be noted that terms such as interlanguage, interculture, and L2 have been admittedly coalesced here. This is because they are taken to be inextricable in the communicational realm this article addresses - namely, use of MIM to engage in natural conversation using at least one participant's L2. This setting would imply, at least in very general terms, some distinction in the interactants' languacultural background; but at minimum, the use of an L2 itself may implicate questions of interculturality in a user's contact with the L2, inasmuch as the language embodies cultural associations. At the same time, this article has addressed text-based MIM without commenting on platforms which allow personal chat on PCs as well as mobile devices, such as Facebook and Snapchat. Social networks of this kind offer another illuminating outlet for interlanguage study, but differences in platform capability and usage may justify some discretely focused investigation.

As claimed here, communication through MIM can lend significant insight to a number of L2 fields of study, and ILP is no exception. Indeed, interlanguage speakers' use of MIM may be all the more study-worthy because of the common ground built at the nexus of cultures-of-use and intercultures. When less readily available or salient, common ground is made achievable 
through some measure of ad hoc negotiations of meaning and conventions for verbal and nonverbal transmission. In mobile messaging exchanges, users may also negotiate the status of stylistic and other conventions, such as punctuation and emojis, playfulness, greetings and closings, etc. In synthesis, MIM interactants take into account interconnected social and technological knowledge including (1) previous languacultural knowledge, (2) co-constructed languacultural meanings, (3) prior medium and genre experience, and (4) immediate medium and genre dynamics. While "culture" in neither sense should be preemptively exaggerated, this particular intersection of electronicallymediated interculturality is a potentially revealing realm which has yet to be examined in ILP. Given the extent of intercultural and culture-of-use-related ad hoc work which is likely to occur in interlinguistic intercultural MIM, datadriven methods may be particularly amenable to its investigation.

This article has (1) discussed mobile communication research in ILP, which thus far has fallen primarily under instructional pragmatics, (2) advocated investigation into interlanguage speakers' pragmatic behavior through natural MIM communication, (3) contemplated certain aspects of interlinguistic intercultural MIM which have implications for its analysis, and (4) recommended emic methods such as modernized conversation analysis for future investigations into mediated interlanguage use. Data-based inquiries into these issues are nonetheless lacking, which highlights the second point: future research has the opportunity, and the calling, to investigate ILP in the bonanza of MIM.

\section{References}

ALCÁNTARA-PLÁ, Manuel. Las unidades discursivas en los mensajes instantáneos de wasap. Estudios de Lingüística del Espanol, Bellaterra, v. 35, p. 223-242, 2014.

ANDÚJAR, Alberto. Benefits of mobile instant messaging to develop ESL writing. System, [s. l.], v. 62, p. 63-76, 2016. https://doi.org/10.1016/j.system.2016.07.004

AVCI, Hulya; ADIGUZEL, Tufan. A case study on mobile-blended collaborative learning in an English as a foreign language (EFL) context. International Review of Research in Open and Distributed Learning, [s. l.], v. 18, n. 7, p. 45-58, 2017. https://doi.org/10.19173/irrodl.v18i7.3261
BARDOVI-HARLIG, Kathleen. Exploring the pragmatics of interlanguage pragmatics: definition by design. In: TROSBORG, Anna (ed.). Pragmatics across languages and cultures. Berlin: De Gruyter Mouton, 2010. v. 7, p. 219-259. https://doi.org/10.1515/9783110214444.2.219

BARHOUMI, Chokri. The effectiveness of WhatsApp mobile learning activities guided by activity theory on students' knowledge management. Contemporary Educational Technology, [s. l.], v. 6, n. 3, p. 221-238, 2015.

BARON, Naomi S. Always on. Oxford: Oxford University Press, 2008.

BAYM, Nancy K. The emergence of community in computer-mediated communication. In: JONES, Steven G. (ed.). Cybersociety: computer-mediated communication and community. Thousand Oaks: Sage, 1995. p. 138-163. https://doi.org/10.1177/146045829500100315

BLAKE, Robert. Computer mediated communication: a window on L2 Spanish interlanguage. Language Learning \& Technology, [s. l.], v. 4, n. 1, p. 111-125, 2000.

BOUHNIK, Dan; DESHEN, Mor. WhatsApp goes to school: mobile instant messaging between teachers and students. Journal of Information Technology Education: Research, v. 13, p. 217-231 2014. https://doi.org/10.28945/2051

BURSTON, Jack. The reality of MALL: Still on the fringes. CALICO Journal, [s. l.], v. 31, n. 1, p 103-125, 2014. https://doi.org/10.11139/cj.31.1.103-125

CHUN, Dorothy M. Developing intercultural communicative competence through online exchanges. CALICO Journal, [s. l.], v. 28, n. 2, p. 392-419, 2011. https://doi.org/10.11139/cj.28.2.392-419

CLOUGH, Gill et al. Informal learning evidence in online communities of mobile device enthusiasts. In: ALLY, Mohamed (ed.). Mobile learning: transforming the delivery of education and training. Edmonton: Athabasca University Press, 2009. p. 99-112.

CONNOLLY, John H.; PHILLIPS, Ian W. On the analysis of multimodal documents at the level of pragmatics. [S. l.: s. n., 2005]. Disponível em: https://pdfs.semanticscholar.org/5793/ f19f5ca05e42055483ce6acfad6d628b3fc2.pdf. Acesso em: 23 nov. 2016

CONSTINE, Josh. Facebook survives $Q 4$ despite slowest daily user growth ever. [S. l.: s. n.] 2018. Disponível em: https://techcrunch.com/2018/01/31/facebook-q4-2017-earnings/? ga=2.31674808.747727270.1554211239-1797793367.1554211239. Acesso em: 2 abr. 2019

COPE, Bill; KALANTZIS, Mary. The things you do to know: an introduction to the pedagogy of multiliteracies. In: COPE, Bill; KALANTZIS, Mary (ed.). A pedagogy of multiliteracies: learning by design. London: Palgrave Macmillan, 2015. p. 1-36. https://doi.org/10.1057/9781137539724_1 
CRYSTAL, David. The fight for English: how language pundits ate, shot, and left. Oxford: Oxford University Press, 2006.

DASHTESTANI, Reza. Moving bravely towards mobile learning: Iranian students' use of mobile devices for learning English as a foreign language. Computer Assisted Language Learning, [s. l.], v. 29, n. 4, p. 815-832, 2016. https://doi.org/10.1080/09588221.2015.1069360

DUCATE, Lara; LOMICKA, Lara. Going mobile: Language learning with an iPod touch in intermediate French and German classes. Foreign Language Annals, New York, v. 46, n. 3, p. 445-468, 2013. https://doi.org/10.1111/flan.12043

DRESNER, Eli; HERRING, Susan C. Functions of the nonverbal in CMC: Emoticons and illocutionary force. Communication Theory, Malden, v. 20, n. 3, p. 249-268, 2010. https://doi. org/10.1111/j.1468-2885.2010.01362.X

FIRTH, Alan. The discursive accomplishment of normality: on conversation analysis and 'lingua franca' English. Journal of Pragmatics, Amsterdam, v. 26, n. 2, p. 237-259, 1996. https:// doi.org/10.1016/0378-2166(96)00014-8

GIBSON, Will. Intercultural communication online: conversation analysis and the investigation of asynchronous written discourse. Forum: Qualitative Social Research, [s. l.], v. 10, n. 1, art. 49, 2009.

GONZÁLEZ-LLORET, Marta. Computer-mediated learning of L2 pragmatics. In: ALCÓNSOLER, Eva; MARTÍNEZ-FLOR, Alicia (ed.). Investigating pragmatics in foreign language learning, teaching and testing. Bristol: Multilingual Matters, 2008. p. 114-132. https://doi. org/10.21832/9781847690869-008

GONZÁLEZ-LLORET, Marta. Conversation analysis and speech act performance. In: MARTÍNEZFLOR, Alicia; USÓ-JUAN, Esther (ed.). Speech act performance: theoretical, empirical and methodological issues. Amsterdam: John Benjamins Publishing Company, 2010. p. 57-73. https://doi.org/10.1075/lllt.26.04gon

GUTIÉRREZ-COLON PLANA, Mar; GALLARDO-TORRANO, Pere; GROVA, M. Elisa. SMS as a learning tool: an experimental study. The EUROCALL Review, [s. l.], v. 20, n. 2, p. 33-47, 2013. https://doi.org/10.4995/eurocall.2012.11376

HAGGAN, Madeline. Text messaging, pragmatic competence, and affective facilitation in the EFL context: a pilot study. Canadian Journal of Applied Linguistics, [s. l.], v. 13, n. 2, p. 150-164, 2010.
HERRING, Susan C. Computer-mediated discourse. In: SCHIFFRIN, Deborah; TANNEN, Deborah; HAMILTON, Heidi E. (ed.). The handbook of discourse analysis. Malden: Blackwell, 2001. p. 612634. https://doi.org/10.1111/j.1467-971x.2008.00544.X

HERRING, Susan C. A faceted classification scheme for computer-mediated discourse. Language@Internet, [S. l.], v. 4, n. 1, p. 1-37, 2007. https://doi.org/10.1515/mc-2015-0016

HERRING, Susan C. Relevance in computer-mediated conversation. In: HERRING, Susan C; STEIN Dieter; VIRTANEN, Tuija (ed.). Handbook of pragmatics of computer-mediated communication Berlin: Mouton de Gruyter, 2013. p. 245-268. https://doi.org/10.1515/mc-2015-0016

HOUSE, Juliane. English as a lingua franca: a threat to multilingualism? Journal of Sociolinguistics, [s. l.], v. 7, n. 4, p. 556-578, 2003. https://doi.org/10.1111/j.1467-9841.2003.00242.X

KASPER, Gabriele. Variation in interlanguage speech act realization. University of Hawai'i Working Papers in ESL, [s. l.], v. 7, n. 2, p. 117-142, 1988.

KATZ, James E.; AAKHUS, Mark A. (ed.). Perpetual contact, mobile communication, private talk public performance. Cambridge: Cambridge University Press, 2002. https://doi.org/10.1017/ cbog780511489471

KECSKÉS, István. Dueling contexts: a dynamic model of meaning. Journal of Pragmatics, Amsterdam, v. 40, n. 3, p. 385-406, 2008. https://doi.org/10.1016/i.pragma.2007.12.004

KECSKÉS, István. Interculturality and intercultural pragmatics. In: JACKSON, Jane (ed.). The Routledge handbook of language and intercultural communication. London: Routledge, 2012. p. 85-102. https://doi.org/10.4324/9780203805640.ch

KECSKÉS, István. Intercultural pragmatics. Oxford: Oxford University Press, 2014.

KOOLE, Tom; TEN THIJE, Jan D. The reconstruction of intercultural discourse: Methodological considerations. Journal of Pragmatics, Amsterdam, v. 33, n. 4, p. 571-587, 2001. https://doi. org/10.1016/s0378-2166(00)00035-7

LEANDER, Kevin M.; VASUDEVAN, Lalitha. Multimodality and mobile culture. In: JEWITT, Carey (ed.). The Routledge handbook of multimodal analysis. London: Routledge, 2009. p. 127-139.

LEVY, Mike; KENNEDY, Claire. Learning Italian via mobile SMS. In: KUKULSKA-HULME, A. TRAXLER, J. (ed.). Mobile learning: a handbook for educators and trainers. London: Routledge, 2005. v. 1, p. 76-83. https://doi.org/10.19173/irrodl.v8i2.437 
MAURANEN, Anna. Signalling and preventing misunderstanding in English as lingua franca communication. International Journal of the Sociology of Language, Berlin, n. 177, p. 123-150, 2006. https://doi.org/10.1515/ijsl.2006.008

MCSWEENEY, Michelle A. The pragmatics of text messaging: making meaning in messages. London: Routledge, 2018. https://doi.org/10.4324/9781315142340

MEIERKORD, Christiane. Interpreting successful lingua franca interaction: an analysis of non-native/non-native small talk conversations in English. Linguistik Online, [s. l.], v. 5, n. 1, 2000. Disponível em: https://bop.unibe.ch/linguistik-online/article/view/1013/1673. Acesso em: 21 out. 2019

MILLER, Vincent. New media, networking and phatic culture. Convergence, Luton, v. 14, n. 4, p. 387-400, 2008.

MORATÓ-PAYÁ, Ana. El WhatsApp como complemento de aprendizaje en la clase de E/LE. Foro de Profesores de E/LE, [s. l.], v. 10, p. 165-173, 2014. https://doi.org/10.7203/foroele.14.13360

MYERS-SCOTTON, Carol (ed.). Codes and consequences: choosing linguistic varieties. Oxford: Oxford University Press, 1998.

RUFFERTY, Irene. 50 texting statistics that can quench everyone's curiosity, even mine. [S. l.: s. n.], 2017. Disponível em: https://medium.com/bsg-sms/50-texting-statistics-that-can-quencheveryones-curiosity-even-mine-7591b61031f5. Acsso em: 2 abr. 2019.

SACKS, Harvey; SCHEGLOFF, Emanuel A.; JEFFERSON, Gail. A simplest systematics for the organization of turn-taking for conversation. Language, [s. l.], v. 50, n. 4, p. 696-735, 1974. https://doi.org/10.1353/lan.1974.0010

SCHANDORF, Michael. Mediated gesture: paralinguistic communication and phatic text. Convergence, Luton, v. 19, n. 3, p. 319-344, 2012. https://doi.org/10.1177/1354856512439501

SCOLLON, Ron; SCOLLON, Suzanne Wong; JONES, Rodney H. Intercultural communication: a discourse approach. 3rd ed. Malden: John Wiley \& Sons, 2012. https://doi.org/10.1017/ s0047404500222045

SHUTER, Robert. Intercultural new media studies: the next frontier in intercultural communication. Journal of Intercultural Communication Research, [s. l.], v. 41, n. 3, p. 219-237, 2012. https://doi.org/10.1080/17475759.2012.728761

SHUTER, Robert; CHATTOPADHYAY, Sumana. Emerging interpersonal norms of text messaging in India and the United States. Journal of Intercultural Communication Research, [s. l.], v. 39, n. 2, p. 123-147, 2010. https://doi.org/10.1080/17475759.2010.526310
SLICKTEXT. 44 Mind-blowing SMS marketing and texting statistics. [S. l.: s. n.], 2019. Disponível em: https://www.slicktext.com/blog/2018/11/44-mind-blowing-sms-marketing-and-textingstatistics/. Acesso em: 2 abr. 2019.

SONG, Yanjie; FOX, Robert. Using PDA for undergraduate student incidental vocabulary testing. ReCALL, [s. l.], v. 20, n. 3, p. 290-314, 2008. https://doi.org/10.1017/s0958344008000438

SOTILLO, Susana M. Discourse functions and syntactic complexity in synchronous and asyncronous communication. Language Learning \& Technology, [s. l.], v. 4, n. 1, p. 82-119, 2000

SPAGNOLLI, Anna; GAMBERINI, Luciano. Action in hybrid environments: why technical interferences do not necessarily 'break' the virtual presence. In: SCHORR, Angela; SELTMANN, Stefan (ed.). Changing media markets in Europe and abroad: new ways of handling information and entertainment content. Lengerich: Pabst Science, 2006. p. 359-375.

SYKES, Julie M. Synchronous CMC and pragmatic development: effects of oral and written chat. CALICO Journal, [s. l.], v. 22, n. 3, p. 399-431, 2005. https://doi.org/10.1558/cj.v22i3.399-431

THORNE, Steven L. Artifacts and cultures-of-use in intercultural communication. Language Learning \& Technology, [s. l.], v.7, n. 2, p. 38-67, 2003

THORNE, Steven L. The "intercultural turn" and language learning in the crucible of new media. In: GUTH, Sarah; HELM, Francesca (ed.). Telecollaboration 2.0: language, literacies and intercultural learning in the 21st century. Bern: Peter Lang, 2010. v. 2, p. 139-164. https://doi org/10.5565/rev/jtl3.498

THORNE, Steven L.; REINHARDT, Jonathon; GOLOMBEK, Paula. Mediation as objectification in the development of professional discourse: a corpus-informed curricular innovation. In LANTOLF, James P.; POEHNER, Matthew E. Sociocultural theory and the teaching of second languages. Sheffield: Equinox, 2008. p. 256-284

THURLOW; Crispin; POFF, Michele. Text messaging. In: HERRING, Susan C.; STEIN, Dieter VIRTANEN, Tuija (ed.). Pragmatics of computer-mediated communication. Berlin: Walter de Gruyter, 2013. p. 163-189. https://doi.org/10.1515/mc-2015-0016

UEBERWASSER, Simone; STARK, Elisabeth. What's up, Switzerland? A corpus-based research project in a multilingual country. Linguistik Online, [s. l.], v. 84, n. 5, 2017. Disponível em: https:// bop.unibe.ch/linguistik-online/article/view/3849. Acesso em: 22 out. 2019.

VANDERGRIFF, Ilona. "My major is English, belive it or not:)": participant orientations in nonnative/native text chat. CALICO Journal, [s. l.], v. 30, n. 3, p. 393-409, 2013. https://doi. org/10.11139/cj.30.3.393-409 
WALTHER, Joseph B. Interpersonal effects in computer-mediated interaction: a relational perspective. Communication Research, Beverly Hills, v. 19, n. 1, p. 52-90, 1992. https://doi. org/10.1177/009365092019001003

WALTHER, Joseph B. Theories of computer-mediated communication and interpersonal relations. In: KNAPP, Mark L.; DALY, John A. (ed.). The handbook of interpersonal communication. London: Sage, 2011. v. 4, p. 443-479.

WALTHER, Joseph B.; LOH, Tracy; GRANKA, Laura. Let me count the ways: the interchange of verbal and nonverbal cues in computer-mediated and face-to-face affinity. Journal of Language and Social Psychology, Clevedon, v. 24, n. 1, p. 36-65, 2005. https://doi.org/10.1177/0261927x04273036

WARSCHAUER, Mark. Motivational aspects of using computers for writing and communication.

In: WARSCHAUER, Mark (ed.). Telecollaboration in foreign language learning: proceedings of the Hawai'i symposium. Honolulu: Hawai'i: University of Hawai'I, 1996. (Technical Report, n. 12). p. $29-46$.

WENGER, Etienne. Communities of practice: learning, meaning, and identity. New York: Cambridge University Press, 1998.

WISE, Michael. 15 text messaging statistics every business should know. [S. l.: s. n., 2018]. Disponível em: https://intelligentcontacts.com/15-text-messaging-statistics-every-business-shouldknow/. Acesso em: 2 abr. 2019. https://doi.org/10.1201/9780849383977.sec1

YUS, Francisco. Cyberpragmatics: internet-mediated communication in context. Amsterdam: John Benjamins Publishing Company, 2011.

YUS, Francisco. Not all emoticons are created equal. Linguagem em (Dis)curso, Tubarão, v. 14 n. 3, p. 511-529, 2014. https://doi.org/10.1590/1982-4017-140304-0414

ZENG, Gang; TAKATSUKA, Shigenobu. Text-based peer-peer collaborative dialogue in a computer-mediated learning environment in the EFL context. System, [s. l.], v. 37, n. 3, p. 434446, 2009. https://doi.org/10.1016/j.system.2009.01.003 